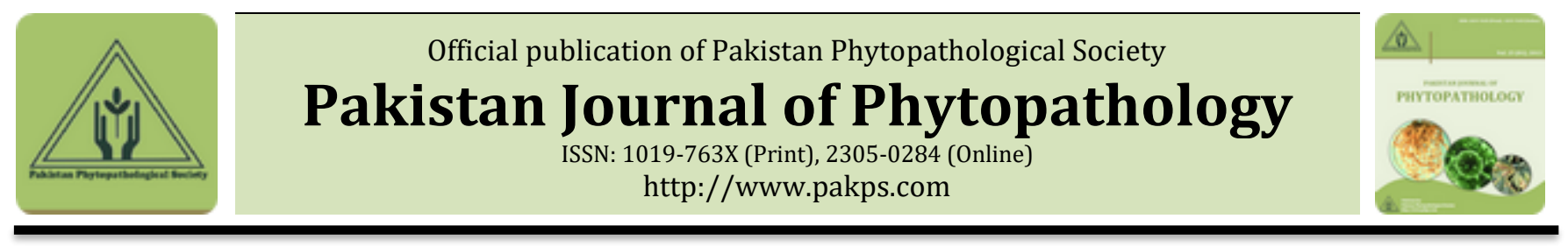

\title{
EVALUATION OF NUTRITIONAL AMENDMENTS, PLANT EXTRACTS AND CHEMICALS FOR THE MANAGEMENT OF STEM ROT OF RICE
}

\author{
aSafdar Ali*, aSahar Anjum, cMuhammad A. Zeshan, bMuhammad Arshad, dNadeem Ahmed, \\ eMuhammad U. Ghani \\ a Department of Plant Pathology, University of Agriculture, Faisalabad, Pakistan. \\ ${ }^{b}$ Department of Entomology, University of Agriculture, Faisalabad, Pakistan. \\ cDepartment of Plant Pathology, University College of Agriculture, University of Sargodha, Sargodha, Pakistan. \\ ${ }^{d}$ Department of Plant Pathology, Muhammad Nawaz Sharif University of Agriculture, Multan, Pakistan. \\ eInstitute of Soil and Environmental Sciences, University of Agriculture Faisalabad, Pakistan.
}

\begin{abstract}
A B S T R A C T
Rice is the staple food of more than one third of world population. The emerging threat to this crop is the stem rot of rice. It is one of the dangerous disease causing huge losses to rice crop worldwide. In-vitro experiments were performed for evaluation of three plant extracts (Eucalyptus globules, Azadirachta indica and Alstonia scholaris) was done at three concentrations $(10 \%, 5 \%$ and $2.5 \%)$ by poison food technique against the causal fungus, Sclerotium oryzae. Eucalyptus extract was found the most effective followed by neem and devil. Similarly, three fungicides, Thiophenate methyl 70\% WP, Difenoconazole 10\% WDG and Azoxystrobin 50\% WDG were also tested at three concentrations $(\mathrm{R}, \mathrm{R} / 2 \& \mathrm{R} / 4)$ and among these Thiophenate methyl 70\%WP was the most effective followed by Difenoconazole 10\% WDG and Azoxystrobin 50\% WDG. The field trial based on 11 treatments comprising of organic nutritional amendments, plant extracts and fungicides was conducted using RCBD. It revealed that mixture of all organic nutritional amendments in combination with Thiophenate methyl fungicide showed significant response in the reduction of disease incidence. Moreover, these amendments also improved the plant growth and yield parameters i.e. plant height, panicle length $(\mathrm{cm})$, number of tillers per plant, number of kernels per panicle, 1000 grain weight and yield/plant.
\end{abstract}

Keywords: Rice, Stem rot, Sclerotium oryzae

\section{INTRODUCTION}

Stem rot incited by Sclerotium oryzae Catt. is one of the most devastating disease which prevails in all rice growing areas worldwide (Konthojam et al., 2007). It was first reported on rice from Italy in 1876 (Cattaneo, 1877). Worldwide 5-80 \% yield loss has been reported due to this disease (Gopika et al., 2016). In Pakistan stem rot was reported in 1970 with $72 \%$ yield losses from different areas of Punjab (Shafi, 1970).

S. oryzae is a soil-borne fungus that produces sclerotia

Submitted: March, 16, 2017

Revised: December, 20, 2017

Accepted for Publication: December 22, 2017

* Corresponding Author:

Email: safdar147m@uaf.edu.pk

(C) 2017 Pak. J. Phytopathol. All rights reserved. with 170-580 $\mu \mathrm{m}$ diameter (Park and Bertus, 1932) which are black at maturity and covered with cotton like mycelium (Cralley and Tullis, 1935). These sclerotia serve as primary source of inoculums and survive in the soil and crop residues up to six years (Krause and Webster, 1973).

Tillering and internodes elongation is the most susceptible stages of rice against stem rot disease (Krause and Webster, 1973). The fungus mainly affects the stem near soil line (Kumar et al., 2003). Initially, it infects leaf sheath, followed by rottening of stem tissues and produce new sclerotia which release in soil at harvesting and cause infection to next season rice crop. Infection usually occurred at hollow internodes of stem (Keim and Webster, 1974; Bockus et al., 1978). Black angular lesions are produced just 
after tillering that causes the death of leaf sheath (Groth and Hollier, 2010).

The host plant resistance is the most valuable source of disease management but rice plant resistance against stem rot is rarely determined from all the rice producing countries of world (Raina et al., 1980; Cother, 1998; Cother and Nicol, 1999). The present study was aimed to find out the eco-friendly management strategies particularly based on organic nutritional amendments and plant extracts which decreases the use of chemicals.

\section{MATERIALS AND METHODS}

\section{In-vitro evaluation of fungicides and plant extracts}

Plant extracts preparation: The leaves of three plants i.e. Azadirachta indica (Neem), Alstonia scholaris (Devil's tree) and Eucalyptus globolus (Sufaida) were collected and thoroughly washed. The leaves were extracted in distilled water; 10 grams of leaves were added in $100 \mathrm{ml}$ of distilled water and grinded in a grinder for preparation of standard/stock solution "S (10\%)". This mixture was filtered using whatman No.1 filter paper (Odey et al., 2012).

Isolation of Pathogen: Stem rot diseased samples were collected from Rice Research Institute, Kala Shah Kaku

$$
\% \text { inhibition }=\frac{\text { Diameter of colony in control }- \text { Diameter of colony in treatment }}{\text { Diameter of colony in control }} \times 100
$$

The best proved extract was further evaluated in field condition separately as well as in-combination with other treatments.

Preparation of fungicidal formulations: Three fungicides Difenoconazole (10\% WDG), Azoxystrobin (50\% WDG) and Thiophenate methyl (70\% WP) were tested against Sclerotium oryzae. Three doses/concentrations $\mathrm{R}, \mathrm{R} / 2$ and $\mathrm{R} / 4$ of each fungicide were prepared for testing against $S$. oryzae. For preparation of dose $\mathrm{R}$ the recommended dose of fungicides was used. The recommended doses of Thiophenate methyl 70\% WP, Azoxystrobin 50\% WDG

$$
\% \text { inhibition }=\frac{\text { Diameter of colony in control }- \text { Diameter of colony in treatment }}{\text { Diameter of colony in control }} \times 100
$$

The best proved fungicide was further evaluated in field condition separately as well as in-combination with other treatments.

\section{In-vivo evaluation of nutritional amendments, plant extract \& fungicide}

Field design: A field study was conducted to determine and compare the effects of alternative treatments against $S$. oryzae in order to avoid the increased use of fungicides for reduction of stem rot disease incidence
(Pakistan). The samples were cut into small pieces of 3-5 $\mathrm{mm}^{2}$ size and disinfected in $1.0 \%$ sodium hypochlorite solution followed by two washings in sterilized distilled water. The sterilized pieces were dried by placing on blotter paper and placed on potato dextrose agar (PDA) plates in laminar air flow chamber. These plates were incubated at $25 \pm 2^{\circ} \mathrm{C}$ for 5-7 days and fungal growth was observed daily. Initially whitish or grayish black mycelial growth was observed which turned into black at maturity with the formation of black sclerotia.

Anti-fungal activity test of extracts: In-vitro evaluation of plant extracts was performed by using a standard poisoned food technique. Three concentrations $(\mathrm{S}, \mathrm{S} / 2$ and $S / 4$ ) of plant extracts were used. The concentration $\mathrm{S} / 2$ and $\mathrm{S} / 4$ were made from the standard solution "S". $\mathrm{S} / 2$ was half of standard while third $\mathrm{S} / 4$ was the quarter of standard. The mature sclerotia of the fungus were inoculated in the centre of the plate and incubated at $28 \pm 2^{\circ} \mathrm{C}$ for $7-10$ days. The radial growth of the desired fungus was recorded daily. Effects of three concentrations of three plant extracts were recorded on the basis of colony diameter and percent inhibition of pathogen by using following formula:

and Difenoconazole 10\% WDG were $2 \mathrm{~g} / \mathrm{L}, 1 \mathrm{~g} / \mathrm{L}$ and $1.2 \mathrm{~g} / \mathrm{L}$, respectively. The second dose $\mathrm{R} / 2$ was half of standard solution and the third dose $\mathrm{R} / 4$ was quarter of the recommended dose.

Anti-fungal activity test of fungicides: Poisoned food technique was used for the evaluation of three concentrations of three different fungicides. The mature Sclerotia of the fungus were inoculated in the centre of the plate and incubated at $28 \pm 2^{\circ} \mathrm{C}$ for $7-10$ days. The radial growth of the desired fungus was recorded daily. Colony diameter and percentage of inhibition of pathogen by using following formula:

and severity as well as for increasing yield. Soil was prepared by using rotavator. After tillage operations, the field was flooded with water and one month old seedlings were transplanted into field under (Randomized Complete Block Design) RCBD. For this the sub-plots were made in each block so that each treatment was applied in a single sub-plot. The size of each sub-plot was 45 inches long and 36 inches wide. Each treatment was replicated thrice within blocks. Each 
sub-plot contained 20 plants with the same row to row and plant to plant distance $(22.5 \mathrm{~cm})$.

Treatments applied after in-vitro evaluation in the field

\begin{tabular}{|c|c|}
\hline Treatments & Remarks \\
\hline Sterculia alata leaves $\left(\mathrm{T}_{1}\right)$ & Organic amendment \\
\hline Farm yard manure $\left(\mathrm{T}_{2}\right)$ & Organic amendment \\
\hline Mushroom compost $\left(\mathrm{T}_{3}\right)$ & Organic amendment \\
\hline Kitchen waste $\left(\mathrm{T}_{4}\right)$ & Organic amendment \\
\hline Eucalyptus extract $\left(\mathrm{T}_{5}\right)$ & Best extract after in-vitro evaluation \\
\hline Thiophenate methyl $\left(\mathrm{T}_{6}\right)$ & Best fungicide after in-vitro evaluation \\
\hline $\mathrm{T}_{5}+\mathrm{T}_{6}$ & Combination of extract and fungicide \\
\hline $\mathrm{T}_{1}+\mathrm{T}_{2}+\mathrm{T}_{3}+\mathrm{T}_{4}$ & Combination of organic amendments \\
\hline$T_{1}+T_{2}+T_{3}+T_{4}+T_{5}$ & Combination of organic amendments + extract \\
\hline $\mathrm{T}_{1}+\mathrm{T}_{2}+\mathrm{T}_{3}+\mathrm{T}_{4}+\mathrm{T}_{6}$ & Combination of organic amendments + fungicide \\
\hline $\begin{array}{l}\text { Three replications were maintained for all these treatments } \\
\text { and single variety Shaheen-Basmati was sown in the } \\
\text { management trials. } \\
\text { All the organic soil amendment separately as well as in } \\
\text { combination was applied before transplanting while extrac } \\
\text { was applied at transplanting. Thiophentae methyl spray } \\
\text { separately as well as in combination with other treatments } \\
\text { was applied when the disease began to appear in the control. }\end{array}$ & $\begin{array}{l}\text { Data recording: } \\
\text { e Plant samples were selected randomly from each } \\
\text { sub-plot for data recording. Data were recorded at } \\
\text { in days interval. Effect of each treatment on the } \\
\text { ct basis of disease incidence and disease decrease over } \\
\text { y control were recorded on selected plants. The } \\
\text { ts formula for incidence and disease decrease over } \\
\text { control is: }\end{array}$ \\
\hline
\end{tabular}

Treatments application: Following treatments were applied in the field after in-vitro evaluation.

$$
\begin{aligned}
\text { Disease incidence }(\%) & =\frac{\text { No. of infected tillers }}{\text { Total no. of selected tillers }} \times 100 \\
\text { Percentage disease decrease over control } & =\frac{\text { Disease in control }- \text { Disease in treatment }}{\text { Disease in control }} \times 100
\end{aligned}
$$

Plant yield and growth parameters: For yield and other plant growth parameters 10 plants were randomly selected. The selected plants were tagged and labeled for each parameter and treatment. These parameters include; number of tillers per plant, panicle length $(\mathrm{cm})$, number of branches per panicle, number of kernels per panicle, plant height, 1000 grain weight $(\mathrm{g})$ and yield per plant $(\mathrm{g})$.

Tillers per plant: Ten plants were randomly selected from each sub-plot, their total and average number of tillers was calculated. Three replications were maintained in the similar way and mean taken. The number of tillers were calculated in the nontreated plots and compared with that of treated plots.

Panicle length (cm): Panicle length of 10 selected tillers was recorded with the help of measuring tape and average was calculated for final study.
Number of branches per panicle: Each panicle has different number of branches/spikelet which varies with environment, variety and time of planting. Number of branches per panicle was recorded for each panicle and average was calculated. Final evaluation is done by taking average of three replications.

Number of kernels per panicle: Number of kernels was calculated for each panicle per plant then average was calculated for each plant. Each replication was the average of 10 plants and three replications were maintained and their average was used for final evaluation.

Plant height: Plant height is measured with measuring tape. For this purpose, 10 plants were randomly selected from each sub-plot and the average height was calculated by taking mean of height of all the selected plants. Mean of three replications was considered for final evaluation. 
1000-grain weight (g): For the calculation of 1000-grain weight the bulk yield of 20 plants of each treatment was sundried for three days.

Yield per plant: Yield per plant was determined after three days continuous sun-drying of the kernels. Average of 10 plants was taken for each replication and average of three replications was used for final evaluation.

Statistical analysis: Recorded data was statistically analyzed by statistics 8.0 software on the basis of ANOVA and least significant difference (LSD-test) at 5\% level of significance.

\section{RESULTS}

Anti-fungal activity test of plant extracts: Among the three tested plant extracts eucalyptus extract was the most effective and it had high inhibitory potential than neem and devil extract. Eucalyptus extract showed percentage of inhibition $27.63 \%$ followed by neem extract $14.84 \%$ and devil extract $11.11 \%$. The results on means are displayed in Table 1 while ANOVA is displayed in Table 2 which revealed significant results.

Table 1. In vitro evaluation of plant extracts against Sclerotium oryzae

\begin{tabular}{|c|c|c|c|}
\hline Sr. No. & Treatments & Colony diameter $(\mathrm{cm})$ & Inhibition percentage (\%) \\
\hline 1. & Control & $3.30 \mathrm{a}$ & $0 \%$ \\
\hline 2. & Devil extract & $2.94 \mathrm{~b}$ & $11.11 \%$ \\
\hline 3. & Neem extract & $2.81 \mathrm{~b}$ & $14.84 \%$ \\
\hline 4 & Eucalyptus extract & $2.39 \mathrm{c}$ & $27.63 \%$ \\
\hline
\end{tabular}

*Mean values are average of 3 replicates.

- Mean values followed by the same letters are not significantly different at $(P<0.05)$.

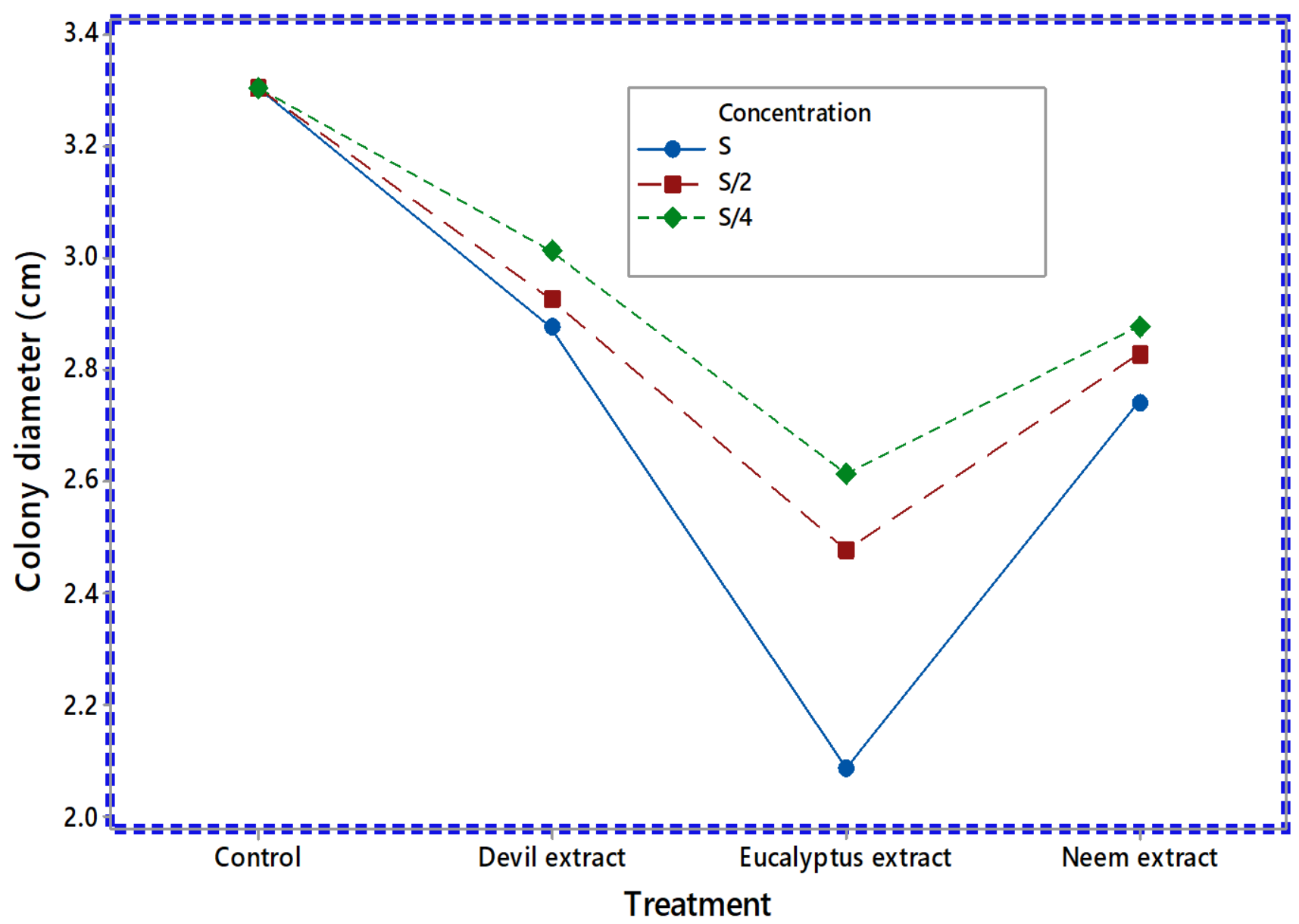

Figure 1. Graph for colony diameter of fungus for evaluation of extracts 


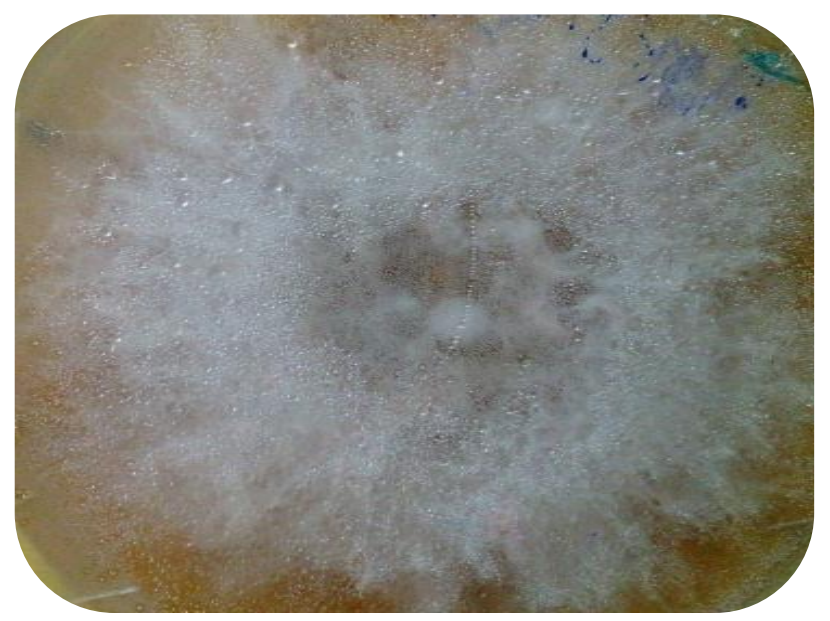

A

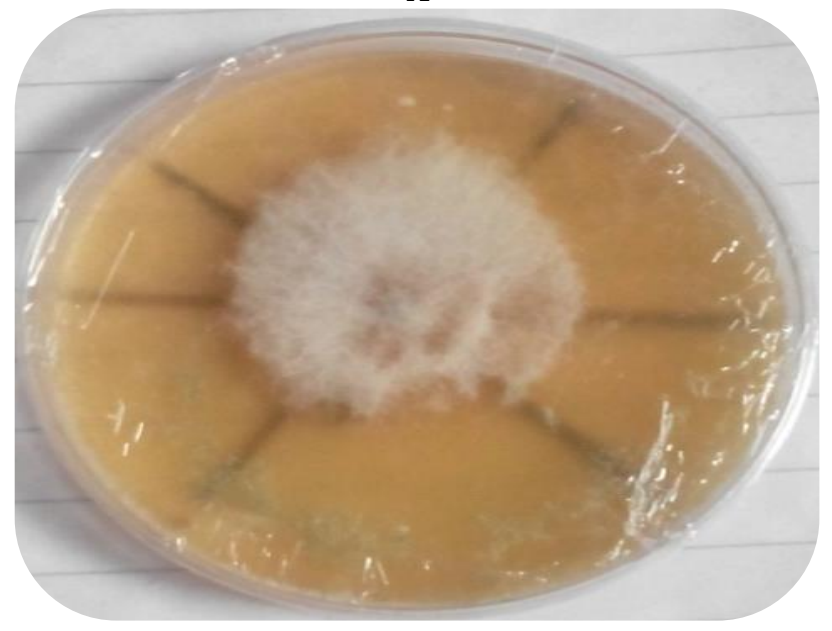

C

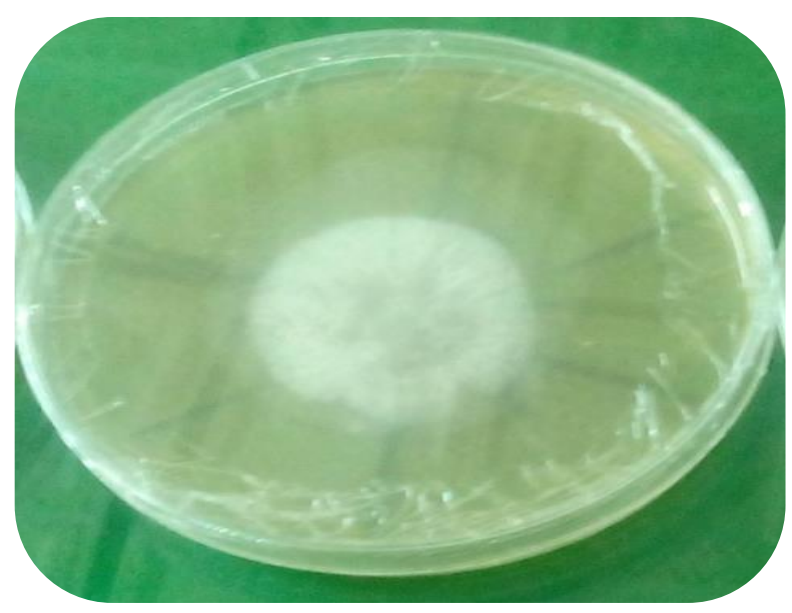

B

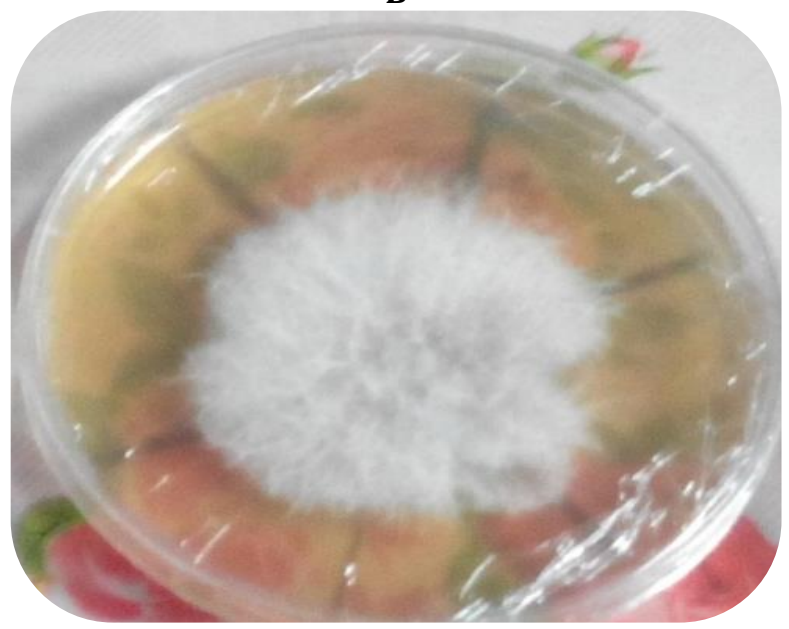

D

Figure 1. Poison Food Technique for evaluation of extracts A. Control plate, B. Eucalyptus extract treated plate $\mathbf{C}$. Neem extract treated plate D. Devil extract treated plate

In-vitro testing of fungicides: Among three tested $42.11 \%$ followed by Difenoconazole $10 \%$ WDG fungicides Thiophenate methyl 70\% WP was found $39.12 \%$ and Azoxystrobin 50\% WDG 22.29\%. The the most effective and it had most inhibitory potential results based on means are displayed in table 3 while than Difenoconazole 10\% WDG and Azoxystrobin 50\% that of ANOVA is in table 4 which revealed significant WDG. Thiophenate methyl 70\% WP showed inhibition results.

Table 3. In vitro evaluation of fungicides against Sclerotium oryzae

\begin{tabular}{clll}
\hline Sr. No. & \multicolumn{1}{c}{ Treatments } & $\begin{array}{l}\text { Colony diameter } \\
(\mathrm{cm})\end{array}$ & Inhibition percentage (\%) \\
\hline 1. & Control & $3.31 \mathrm{a}$ & $0 \%$ \\
\hline 2. & Azoxystrobin 50\% WDG & $2.57 \mathrm{~b}$ & $22.29 \%$ \\
\hline 3. & Difenoconazole10\% WDG & $2.02 \mathrm{c}$ & $39.12 \%$ \\
\hline 4. & Thiophenate methyl 70\% WP & $1.91 \mathrm{c}$ & $42.11 \%$ \\
\hline
\end{tabular}

*Mean values are average of 3 replicates.

- Mean values followed by the same letters are not significantly different at $(P<0.05)$. 


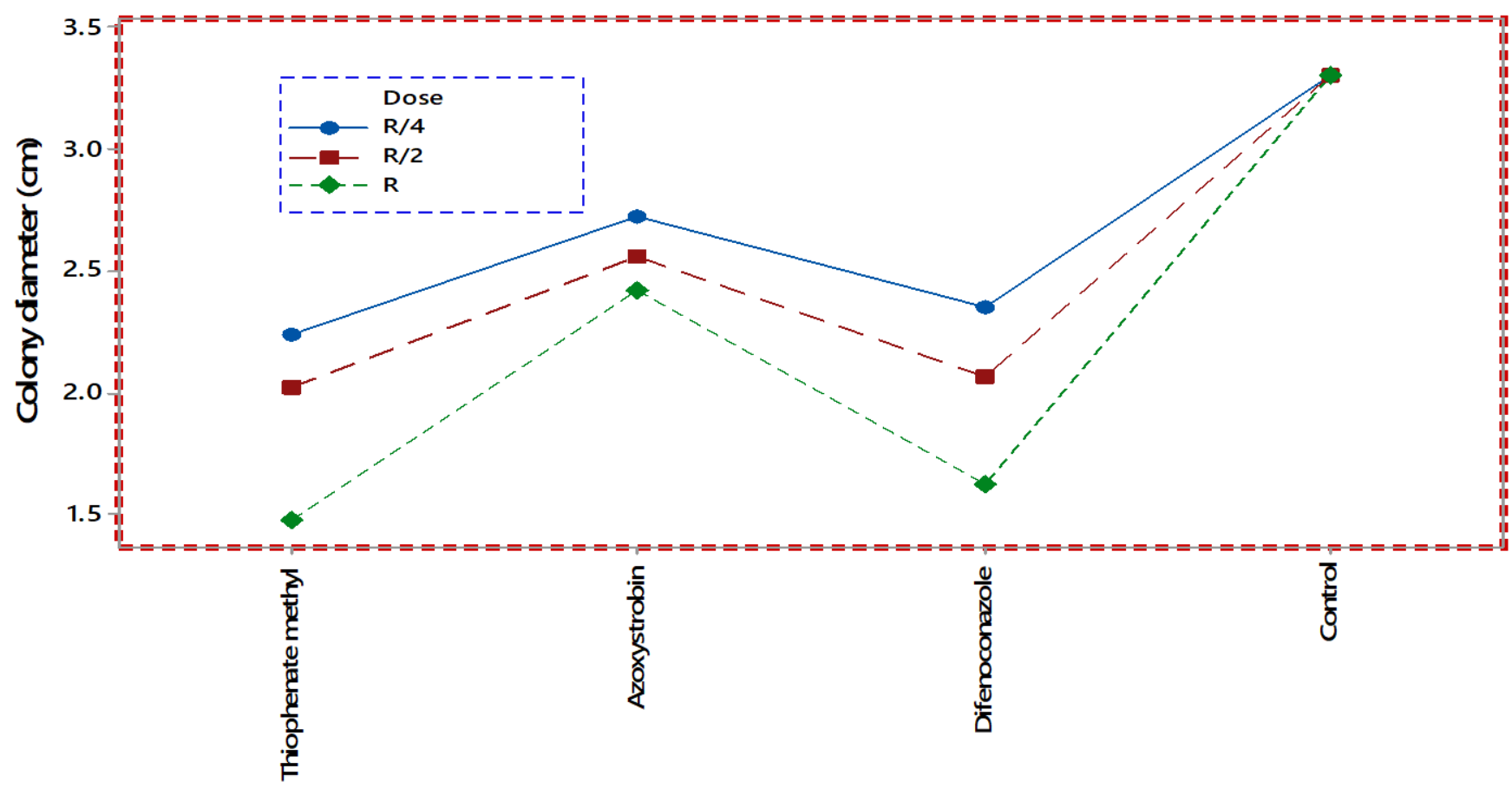

Figure. 2. Graph on colony diameter (cm) of pathogen for evaluation of fungicides
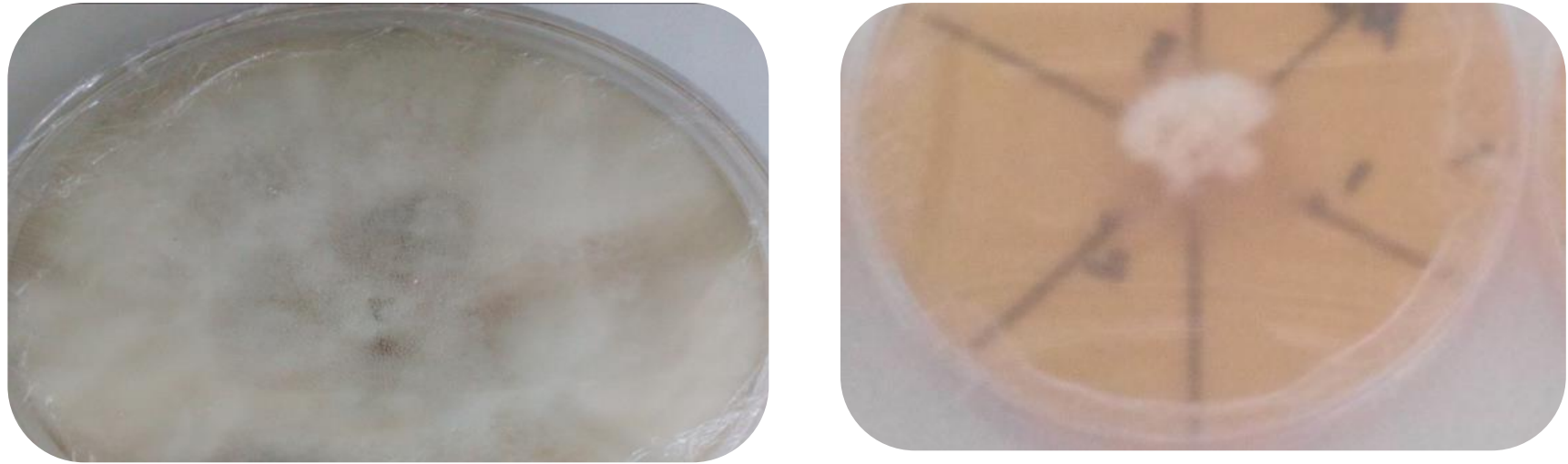

A

B

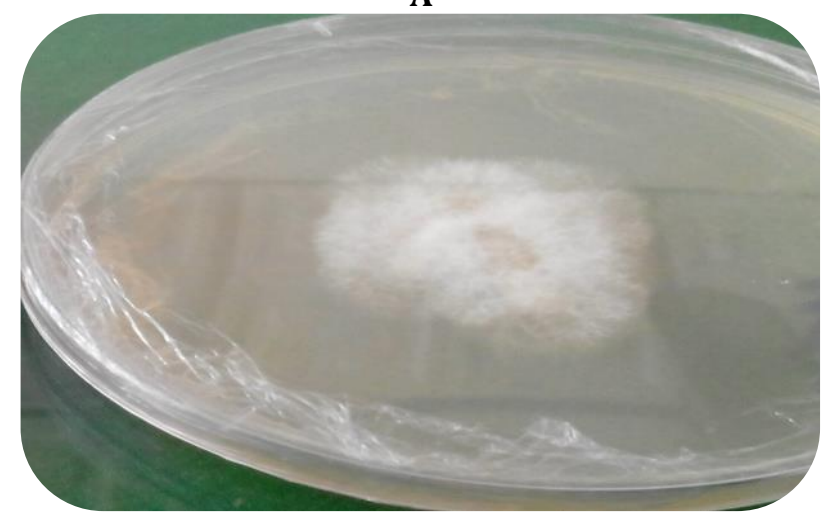

C

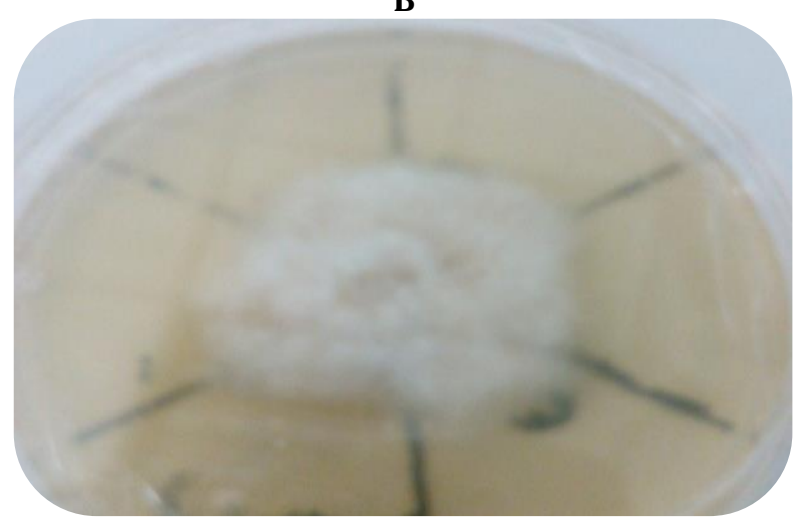

D

Figure 2. Poison Food Technique for evaluation of fungicides A. Control plate, B. Thiophenate methyl treated plate C. Difenoconazole treated plate D. Azoxystrobin treated plate 
In-vivo evaluation of nutritional amendments, plant extracts and fungicides against Sclerotium oryzae:

Among the 11 tested treatments mixture of all the amendments with that of thiophenate methyl gave maximum result among all other treatments while Sterculia alata leaves showed minimum result among all as compared to control. The treatments including mixture of all amendments showed a mean value of disease incidence $5.78 \%$ which had a significant impact on plant health and hindering the stem rot infection and Sterculia alata leaves showed a mean value of $17.57 \%$ as compared to control.

Table 6. Disease incidence and disease decrease over control under field conditions

\begin{tabular}{lll}
\hline Treatment & Disease incidence (\%) & Disease decrease over control (\%) \\
\hline Sterculia alata leaves (T1) & $17.57 \mathrm{~b}$ & $47.653 \mathrm{e}$ \\
\hline Farm yard Manure (T2) & $16.94 \mathrm{~b}$ & $49.578 \mathrm{e}$ \\
\hline Mushroom Compost (T3) & $12.38 \mathrm{c}$ & $63.291 \mathrm{~cd}$ \\
\hline Kitchen waste (T4) & $14.08 \mathrm{~cd}$ & $58.199 \mathrm{~d}$ \\
\hline Eucalyptus extract (T5) & $11.53 \mathrm{de}$ & $65.694 \mathrm{~cd}$ \\
\hline Thiophenate methyl (T6) & $10.27 \mathrm{de}$ & $69.467 \mathrm{bc}$ \\
\hline T5+T6 & $7.15 \mathrm{e}$ & $78.711 \mathrm{a}$ \\
\hline T1+T2+T3+T4 & $10.69 \mathrm{f}$ & $68.243 \mathrm{bc}$ \\
\hline T1+T2+T3+T4+T5 & $8.00 \mathrm{fg}$ & $76.171 \mathrm{ab}$ \\
\hline T1+T2+T3+T4+T6 & $5.78 \mathrm{~g}$ & $82.778 \mathrm{a}$ \\
\hline Control & $33.70 \mathrm{a}$ & $0 \mathrm{f}$ \\
\hline
\end{tabular}

*Mean values are average of 3 replicates.

- Mean values followed by the same letters are not significantly different at $(P<0.05)$.

Effect on yield and growth parameters of rice plants: fungicide (Sterculia alata leaves + farm yard manure + All the organic nutritional amendments as well as mushroom compost + kitchen waste + Thiophenate extract and fungicide showed significant impact on plant methyl) showed most effective results while Sterculia growth and yield parameters. Among eleven tested alata leaves showed least significant results when treatments mixture of all amendments along with compared with control (Table 7).

Table 7. Effect of organic amendments, plant extracts and fungicides on yield and plant growth parameters

\begin{tabular}{|c|c|c|c|c|c|c|c|}
\hline Treatment & $\begin{array}{l}\text { No. of } \\
\text { Tillers/plant }\end{array}$ & $\begin{array}{l}\text { Panicle } \\
\text { length } \\
(\mathrm{cm})\end{array}$ & $\begin{array}{l}\text { No. of } \\
\text { Branches/panicle }\end{array}$ & $\begin{array}{l}\text { No. of } \\
\text { kernals/ } \\
\text { panicle } \\
\end{array}$ & $\begin{array}{l}\text { Plant height } \\
\text { Plant } \\
\text { height }(\mathrm{cm})\end{array}$ & $\begin{array}{l}\text { 1000-grain } \\
\text { Grain } \\
\text { weight }(\mathrm{g})\end{array}$ & $\begin{array}{l}\text { Yield/plant } \\
\text { yield (g) }\end{array}$ \\
\hline $\begin{array}{l}\text { Sterculia alata } \\
\text { leaves (T1) }\end{array}$ & $17.13 \mathrm{e}$ & $18.65 \mathrm{~h}$ & $7.87 \mathrm{f}$ & $72.80 \mathrm{~g}$ & $77.19 \mathrm{~d}$ & $18.97 \mathrm{fg}$ & $30.21 \mathrm{~h}$ \\
\hline $\begin{array}{l}\text { Farm yard manure } \\
\text { (T2) }\end{array}$ & $18.40 \mathrm{~d}$ & $19.41 \mathrm{gh}$ & $8.80 \mathrm{e}$ & $78.60 \mathrm{f}$ & $85.64 c$ & $19.51 \mathrm{ef}$ & $34.16 \mathrm{~g}$ \\
\hline $\begin{array}{l}\text { Mushroom } \\
\text { compost (T3) }\end{array}$ & $19.40 \mathrm{c}$ & $21.29 \mathrm{f}$ & $9.53 \mathrm{~d}$ & $90.27 \mathrm{~d}$ & $89.09 c$ & 20.25 cdef & $36.51 \mathrm{f}$ \\
\hline $\begin{array}{l}\text { Eucalyptus extract } \\
\text { (T5) }\end{array}$ & $19.40 \mathrm{c}$ & $23.44 \mathrm{e}$ & $10.00 \mathrm{~d}$ & $93.33 \mathrm{~d}$ & $89.23 c$ & 20.69 cde & $39.29 \mathrm{e}$ \\
\hline $\begin{array}{l}\text { Thiophenate } \\
\text { methyl (T6) }\end{array}$ & $19.93 \mathrm{bc}$ & $26.51 \mathrm{c}$ & $11.47 \mathrm{c}$ & $105.60 \mathrm{c}$ & $96.06 \mathrm{~b}$ & $21.22 \mathrm{abc}$ & $43.70 \mathrm{c}$ \\
\hline $\mathrm{T} 5+\mathrm{T} 6$ & $20.53 \mathrm{ab}$ & $28.33 b$ & $12.20 \mathrm{~b}$ & $120.80 \mathrm{~b}$ & $98.80 \mathrm{~b}$ & $22.10 \mathrm{ab}$ & $46.88 \mathrm{~b}$ \\
\hline
\end{tabular}

*Mean values are average of 3 replicates.

- Mean values followed by the same letters are not significantly different at $(P<0.05)$.

Data revealed that maximum number of tillers per plant were 21.40 which were produced by plants treated with mixture of all the amendments i.e. Sterculia alata leaves + farm yard manure + mushroom compost + kitchen waste with that of thiophenate methyl and Sterculia alata leaves showed least significant results with mean number of tillers per plant 17.13. Similarly, the maximum mean panicle length $30.33 \mathrm{~cm}$, branches per panicle 13.53 , kernels per panicle were 132.53 , plant height $105.65 \mathrm{~cm}$, 1000 -grain weight $22.28(\mathrm{~g})$, and yield/plant $50.93(\mathrm{~g})$ was 
recorded in combined effect of soil amendments with that of fungicide and minimum mean panicle length was $18.65 \mathrm{~cm}$, number of branches per panicle 7.87 , kernels per panicle 72.80 , plant height $77.19 \mathrm{~cm}, 1000$-grain weight $18.97(\mathrm{~g})$ and yield/plant $30.21(\mathrm{~g})$ was observed in case of sterculia alata leaves.

\section{DISCUSSIONS}

Medicinal plants have great effect for the control of sclerotial diseases. Some plants contain components that are toxic to pathogens (Gurjar et al., 2012). The antimicrobial efficacies of plant extracts against plant diseases have been studied by many scientists (Suberu, 2004). Three plants extracts Alstonia scholaris (Devil), Azadirachta indica (Neem) and Eucalyptus globules (Sufaida) were evaluated in-vitro against S. oryzae and Eucalyptus extract was the most effective in inhibiting the fungal growth followed by neem and devil tree. The results of this experiment have significant resemblance with other researcher's work. Antifungal properties of neem have been described by (Bansal and Sobti, 1990). Khalil (2001) demonstrated that eucalyptus extracts effectively reduces the spore germination of different fungi. Significant reduction in brown leaf spot disease incidence and increase in yield of rice was recorded in neem extracted treated plots (Harish et al., 2008). Jalal and Ghaffar (1992) found that sclerotial growth of Sclerotium rolfsii was significantly reduced by the leaf extracts of Ocimum sanctum L. Similarly, this extract was also used against other related fungi and proved effective as medicinal plant. Dubey et al., (2009) reported that extracts of $A$. indica and E. globules were proved best against suppression of Macrophomina phaseolina sclerotial germination. Moreover, these are not only cost effective but also eco-friendly for controlling plant diseases (Venkateswarlu and Sreeramulu, 2013). The plant extracts cause granulation of cytoplasm, membrane rupture in cytoplasm and inactivation of intracellular and extracellular enzyme synthesis (Cowan, 1999). Chung et al., (1998) stated that plant extracts contain tannins that arrest the growth of fungi.

Fungicides are most commonly used to reduce the economic losses caused by soil-borne diseases. Their ease of application and effectiveness has made them the most common mean to combat many fungal diseases (Vinale et al., 2008; Dias, 2012). In the present experiment, three fungicides Thiophenate methyl $70 \%$ WP, Difenoconazole 10\% WDG and Azoxystrobin 50\%
WDG were used. The results revealed that Thiophenate methyl 70\% WP was the most effective even at lower concentration followed by Difenoconazole 10\% WDG and Azoxystrobin 50\% WDG. These results are in accordance with previous studies. Reddy (1984) conducted a trial on 16 fungicides evaluation against stem rot of rice and results revealed that, carbendazim (Bavistin 50 WP), tridemorph, tolfos - methyl, thiophanate methyl, carboxin (Vitavax 75 WP), ziram and cuman L-27 were highly effective against this disease and reduced the sclerotial germination even at lower concentration. Singh et al., (2002) also reported that Thiophanate methyl was the most effective against stem rot disease among many fungicides. Diafenoconzole and azoxystrobin completely controlled the growth of Lasiodiplodia theobromae on PDA medium (Rehana et al., 2014). Hossain et al., (2011) reported that azoxystrobin reduced the brown leaf spot of rice and increased the yield of rice. The fungicides cause demethylation of ergosterol that inhibits the cell wall formation of fungi and ultimately protects the plants from high disease incidence (Gupta et al., 2013).

Stem end rot disease reduced in the plots treated with organic amendments. The growth and yield parameters significantly increased in treated plots as well. In mature compost sclerotia killed by hyperparasitism (Chen et al., 1988). Salim et al., (2016) described the increased yield and decreased fungal growth by using spent mushroom compost along with Trichoderma harzianum. Melese et al., (2008) used different concentrations of farm yard manure and recorded low disease incidence and high yield of lettuce. Fuchs et al., (2008) concluded after different experiments that composts help in the mobilization and availability of nutrients in the soil that ultimately boosts up the plant defense.

\section{CONCLUSION}

The effect on plant growth and yield parameters was recorded and found that maximum promotion of growth and yield parameters was observed in combination of organic soil amendments, including Farm yard manure, Sterculia alata leaves, mushroom compost and kitchen wastes with that of fungicide, Thiophenate methyl.

\section{REFERENCES}

Bansal, R. and A. Sobti. 1990. An economic remedy for the control of two species of Aspergillus on groundnut. Indian Phytopathology, 43: 451-452.

Bockus, W. W. 1978. The Competitive Saprophytic Ability of Sclerotium oryzae Derived from 
Sclerotia. Phytopathology, 68: 417.

Cattaneo, A. 1877. Sullo Sclerotium oryzae: nuovo parassita vegetale che ha devastato nel corrente anno molte risaje di Lombardia e del Novarese. Tip. Bernasconi.

Chen, W. 1988. The Role of Microbial Activity in Suppression of Damping-Off Caused by Pythium ultimum. Phytopathology, 78: 314.

Chung, K.-T., T. Y. Wong, C.-I. Wei, Y.-W. Huang and Y. Lin. 1998. Tannins and Human Health: A Review. Critical Reviews in Food Science and Nutrition, 38: 421-464.

Cother, E. and H. Nicol. 1999. Susceptibility of Australian rice cultivars to the stem rot fungus Sclerotium oryzae. Australasian Plant Pathology, 28: 85.

Cowan, M. M. 1999. Plant products as antimicrobial agents. Clinical microbiology reviews, 12: 564582.

Cralley, E. and E. Tullis. 1935. A Comparison of Leptosphaeria salvinii and Helminthosporium sigmoideum irregulare. Journal of Agricultural Research, 51: 341-348.

Groth, D. and C. Hollier. 2010. Louisiana Plant Pathology, Disease Identification and Management Strategies: Stem Rot of Rice. Louisiana State University Agricultural Center Research and Extension: 108112.

Dias, M. C. 2012. Phytotoxicity: An Overview of the Physiological Responses of Plants Exposed to Fungicides. Journal of Botany, 2012: 1-4.

Dubey, R., H. Kumar and R. Pandey. 2009. Fungitoxic effect of neem extracts on growth and sclerotial survival of Macrophomina phaseolina in vitro. The Journal of American Science, 5: 17-24.

Fuchs, J. G., A. Berner, J. Mayer, K. Schleiss and T. Kupper. 2008. Effects of compost and digestate on environment and plant production-results of two research projects.

Gopika, K., R. Jagadeeshwar, V. K. Rao and K. Vijayalakshmi. 2016. Comprehensive Management.

Gupta, V., N. Shamas, V. Razdan, B. Sharma, R. Sharma, K. Kaur, I. Singh, D. John and A. Kumar. 2013. Foliar application of fungicides for the management of brown spot disease in rice (Oryza sativa L.) caused by Bipolaris oryzae. African Journal of Agricultural Research, 8: 3303-3309.

Gurjar, M. S., S. Ali, M. Akhtar and K. S. Singh. 2012.
Efficacy of plant extracts in plant disease management. Agricultural Sciences, 03: 425-433.

Harish, S., D. Saravanakumar, R. Radjacommare, E. G. Ebenezar and K. Seetharaman. 2007. Use of plant extracts and biocontrol agents for the management of brown spot disease in rice. BioControl, 53: 555-567.

Hossain, I., P. Dey and M. Z. Hossain. 2012. Efficacy of Bion, Amistar and Tilt in controlling brown spot and narrow brown spot of rice cv. BR11 (Mukta). Journal of the Bangladesh Agricultural University, 9.

Jalal, A. O. and A. Ghaffar. 1992. Antifungal properties of Ocimum sanctum L. National Symposium on the Status of Plant Pathology in Pakistan. Univ. of Karachi. pp. 283-287.

Keim, R. 1974. Effect of Soil Moisture and Temperature on Viability of Sclerotia of Sclerotium oryzae. Phytopathology, 64: 1499.

Khallil, A.-R. M. 2001. Phytofungitoxic Properties in the Aqueous Extracts of Some Plants. Pakistan Journal of Biological Sciences, 4: 392-394.

Konthoujam, J., G. Chhetry and R. Sharma. 2012. Symptomatological significance and characterization of susceptibility/resistance group among low land rice cultivars towards stem rot of rice in Manipur valley. Indian Phytopathology.

Krause, R. A. 1973. Stem rot of Rice in California. Phytopathology, 63: 518.

Kumar, A., R. Singh and B. Jalali. 2003. Management of stem rot of rice with resistance inducing chemicals and fungicides. Indian Phytopathology, 56: 266-226.

Odey, M., I. Iwara, U. Udiba, J. Johnson, U. Inekwe, M. Asenye and 0. Victor. 2012. Preparation of plant extracts from indigenous medicinal plants. International Journal of Science \& Technology, 1: 688-692.

Park, M. and L. Bertus. 1932. Sclerotial diseases of rice in Ceylon. I. Rhizoctonia solani Kühn. Ann. Roy. Botan. Garden (Peradeniya), 11: 319-331.

Raina, G., S. Gurjit and G. Sidhu. 1980. Sources of resistance to major rice diseases in the Punjab, India. International Rice Research Newsletter, 5: 6-7.

Reddy, C. S. 1984 Studies on stem rot disease of rice. Annual report of CRRI: 96-97. 
Salim, H. A., B. N. Jasim, A. D. Kadhim, I. S. Salman and A. A. Abdalbaki. 2016. Effect of Biocontrol, Physical Control and Compost on Tomato Plants that Infected with Fusarium wilt under Greenhouse Conditions. World Journal of Agricultural Research, 5: 5-8.

Shafi, M. 1970. Ten years of rice findings. Kala Shah.

Singh, R., A. Kumar and B. Jalali. 2002. Variability, predisposing factors and management of stem rot of rice caused by Sclerotium oryzae Catt.: An overview. Annual Review of Phytopathology, 1: 275-289.

Suberu, H. 2004. Preliminary studies of inhibitions in Aspergillus flavus with extracts of two lichens and Bentex-T fungicide. African Journal of Biotechnology, 3: 468-472.

Syed, R. N., N. Mansha, M. A. Khaskheli, M. A. Khanzada and A. M. Lodhi. 2014. Chemical control of stem end rot of mango caused by Lasiodiplodia theobromae. Pakistan Journal of Phytopathology, 26: 201-206.

Venkateswarlu, N. and A. Sreeramulu. 2013. In Vitro Evaluation of Selected Plant Extracts on The Mycelial Growth of Sclerotium Oryzae Catt. International Journal of Pharma and Bio-Science, 4: 640-644.

Vinale, F., K. Sivasithamparam, E. L. Ghisalberti, R. Marra, S. L. Woo and M. Lorito. 2008. Trichodermaplant-pathogen interactions. Soil Biology and Biochemistry, 40: 1-10.

Melese, W. 2008. Effect of farm yard manure application rate on yield and yield components of lettuce (Lactuca sativa) at Jimma Southwestern Ethopia. International Journal of Research, 4: 75-83. 